\title{
Quality Analysis of Urea Plant Wastewater and its Impact on Surface Water Bodies
}

\author{
Abdul Nasir Laghari \\ Department of Chemical Engineering \\ Quaid-e-Awam University of \\ Engineering, Science \& Technology \\ Nawabshah, Pakistan \\ mashaalnasirlaghari@gmail.com
}

\author{
Daddan Khan Bangwar \\ Department of Civil Engineering \\ Quaid-e-Awam University of \\ Engineering, Science \& Technology \\ Nawabshah, Pakistan
}

\author{
Zafar Ali Siyal \\ Department of Energy and \\ Environment \\ Quaid-e-Awam University of \\ Engineering, Science \& Technology \\ Nawabshah, Pakistan \\ Abdul Jabbar Khokhar \\ Department of Energy and \\ Environment \\ Quaid-e-Awam University of \\ Engineering, Science \& Technology \\ Nawabshah, Pakistan
}

\author{
MohsinAli Soomro \\ Department of Civil Engineering \\ Quaid-e-Awam University of \\ Engineering, Science \& Technology \\ Nawabshah, Pakistan
}

\author{
Hira Lal Soni \\ Department of Chemical Engineering \\ Quaid-e-Awam University of \\ Engineering, Science \& Technology \\ Nawabshah, Pakistan
}

\begin{abstract}
This study was conducted on the canal water that flows besides an urea manufacturing facility. The study focused to evaluate the impact of facility's effluents. The canal water quality is being affected drastically due to heavy load of pollutants discharged. Samples were collected by grab sampling method, from various locations. These samples were analyzed regarding physiochemical parameters, i.e. temperature, pH, TDS, TSS, BOD $_{5}, \mathrm{COD}$, heavy metals $(\mathrm{Fe}, \mathrm{Cu}, \mathrm{Cr}, \mathrm{Mn})$ and $\mathrm{NH} 3$ content. The canal water quality deteriorates after receiving a substantial load of effluents discharged from urea fertilizer plant. The results compared with WHO and NEQS, showed that the effluent samples had alkaline nature with a high level of ammonia and BOD $_{5}$ and are not safe for aquatic life and environment. It is therefore recommended that discharge of untreated effluents should be stopped, or allowed within safe limits.
\end{abstract}

Keywords-wastewater; water quality; physiochemical analysis

\section{INTRODUCTION}

Water is used for numerous purposes such as food production, irrigation, manufacturing, drinking and waste disposal [1-2]. Due to its unique structure, water has the ability to suspend, dissolve, and absorb a number of compounds that deteriorate the purity of drinking water, as it acquires contaminants from its surroundings [3]. Ground and surface water can be polluted by industrial discharged effluents, sewage water and wastewater from contaminated sources [4]. A significant share of the industrial wastewater is being discharged into the water bodies without any proper treatment, subsequently reducing the quality of drinking water. The untreated water is sometimes also infiltrating aquifers, it causes damages on human health and mainly in the developing countries is the result of lack of safe and wholesome water supply [5]. Many countries have incorporated wastewater reuse as an essential measurement of water resources planning. Certain countries, like Saudi Arabia and Jordan, have attempted to reuse the wastewater after proper treatment and have achieved significant success [6].

The quality of canal water is an issue of grave concern due to the rapid growth in industrial activities in Mirpur Mathelo, Sindh. An urea fertilizer plant releases wastewater with toxic heavy metals and severe physiochemical parameters such as temperature, $\mathrm{pH} \mathrm{BOD}_{5}, \mathrm{COD}$ and ammonia, in the surroundings. Heavy metal contamination of surface water has a potential toxic effect on the environment [7]. The polluted surface water thus threatens agriculture, aquatic life, and is raising both environmental and human health concerns [8]. The characteristics of fertilizer effluents vary depending on the type of fertilizer produced, operating conditions and control mechanism and they must be treated before disposal. Although much work was done in this area of investigation, each industrial wastewater has its own chemical and mineralogical composition which implies that the treatment condition is different from one type of wastewater to another. This work aims to analyze the impact of liquid effluents of urea fertilizer plant on the quality of canal surface water, and on groundwater in nearby habitats of the fertilizer plant in Mirpur Mathelo, Ghotki district, Pakistan. It is found that the quality of surface water has been gradually deteriorating due to the continuous discarding of untreated effluents. The production capacity of ammonia by Haber Bosch process is $1250 \mathrm{MTD}$, and urea synthesized with the chemical reaction of ammonia and carbon dioxide, having a production capacity of 2175 MTD. Wastewater generated in the fertilizer plant is about 5776 MTD. Furthermore, heavy metals are major environmental contaminants, and their toxicity even at low concentration is a threat to ecology and water bodies. 'Heavy metals' are metallic 
elements of many types with relatively high density. Heavy metals observed in ground samples including iron (Fe), copper $(\mathrm{Cu})$, chromium $(\mathrm{Cr})$, and manganese $(\mathrm{Mn})$ [9].

Water contamination affects the health of crops, livestock, and humans. Wastewater irrigation, a common practice in Pakistan, causes metal uptake by crops and therefore, risks the safety of food prepared from them and consequently brings potential hazards to the consumers. In addition to wastewater irrigation practice, agriculture industry in Pakisatn heavily relies upon chemical fertilizers, such as, Di-ammonium phosphate (DAP) and urea are widely used fertilizers in the region. Therefore, it also becomes important to assess the effect of such fertilizers on accumulated metals in soils, i.e., either deposited through wastewater irrigation or due to any other reasons. [10]. Crops grown on contaminated soils bring hazards to both animals and humans. Heavy metals are entered in an animal body, by their feeds, drinking water or through medication [11]. Using wastewater, either from domestic or industrial effluents, may lead to depositing high concentrations of heavy metals on soils; which then concentrated in crop plant tissues and result in damaging the crop itself and the harvest and consequently bringing health hazards to the consumers [12].

\section{MATERIALS AND METHODS}

\section{A. Study Area}

The physiochemical study of the canal surface water was carried out at four different locations. Water samples were analyzed by taking samples in clean polythene bottles without any air bubble from wastewater lagoon (Location 1), 300m downstream from wastewater discharge point (Location 2), $600 \mathrm{~m}$ downstream from wastewater discharge point (Location 3), $900 \mathrm{~m}$ downstream from wastewater discharge point (Location 4), covering thus $1 \mathrm{~km}$ distance along the canal. Surface water samples were then compared with National Environment Quality Standard (NEQS). Samples were collected from each location at 15 day time intervals and were tagged as Sample-1, Sample-2, Sample-3, and Sample-4 respectively. Plastic bottles were first rinsed with de-ionized water, sealed properly after collection and labeled accordingly. Parameters were analyzed in the QUEST laboratory of energy and environment department, Nawabshah. Sampling locations of canal water and ground water are shown in Figures 1 and 2 respectively. The industry which discharges effluents is Fauji Fertilizer Company (FFC) Limited's urea fertilizer plant, situated in Mirpur Mathelo, Ghotki district, Pakistan.

\section{B. Water Sample Analysis}

The samples collected were brought to QUEST environmental engineering department lab, for analysis of physiochemical parameters such as $\mathrm{pH}$, total dissolved solids (TDS), total suspended solids (TSS), biochemical oxygen demand $\left(\mathrm{BOD}_{5}\right)$, chemical oxygen demand (COD), ammonia (NH3) and heavy metal content. The techniques used in characterizations are listed in Table I. Table II shows the standard values of water quality parameters.

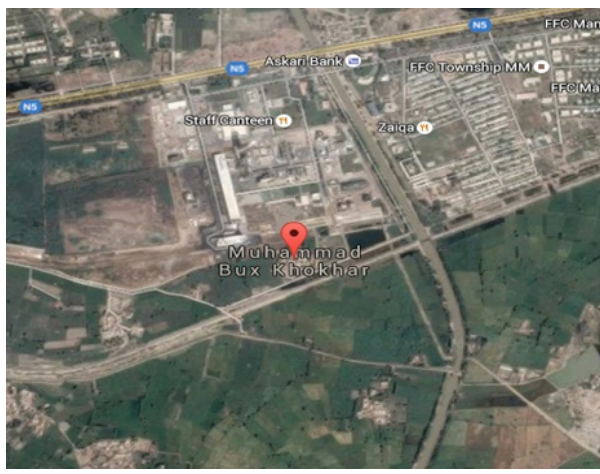

Fig. 1. Surface water sampling locations (Google Earth screenshot)

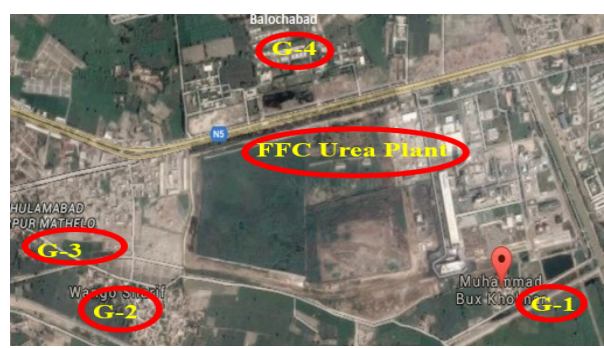

Fig. 2. Ground water sampling locations (Google Earth screenshot)

TABLE I. PHYSIOCHEMICAL PARAMETER MEASUREMENT [4]

\begin{tabular}{|c|c|c|}
\hline Parameter & Technique & $\begin{array}{c}\text { Instrument and } \\
\text { model }\end{array}$ \\
\hline $\mathrm{pH}$ & pH meter & EL430.020 \\
\hline TDS & TDS meter & CON200, Lovibond \\
\hline TSS & TSS meter & PH110, Lovibond \\
\hline BOD $_{5}$ & $\begin{array}{c}\text { BOD bottles with digital } \\
\text { measurement cap and } \\
\text { Incubator }\end{array}$ & 040552, Lovibond \\
\hline $\mathrm{COD}_{\text {Ammonia }}$ & Reactor Digestion Method & ET108, Lovibond \\
\hline Spectrophotometer & $\begin{array}{c}\text { Spectrodirect, } \\
\text { Lovibond }\end{array}$ \\
\hline
\end{tabular}

TABLE II. STANDARD VALUES OF WATER QUALITY PARAMETERS [8]

\begin{tabular}{|c|c|}
\hline Parameters & Limit \\
\hline $\mathrm{pH}$ & $6.5-8.5$ \\
\hline BOD5 & $0.2 \mathrm{mg} / \mathrm{L}$ \\
\hline COD & $4 \mathrm{mg} / \mathrm{L}$ \\
\hline TDS & $1000 \mathrm{mg} / \mathrm{L}$ \\
\hline Turbidity & $10 \mathrm{NTU}$ \\
\hline Color & $15 \mathrm{ptcu}$ \\
\hline
\end{tabular}

\section{RESULTS AND DISCUSSION}

Surface and ground water samples were analyzed to understand the impact of urea fertilizer plant to surface and ground water, impact that harms aquatic life, plants, animals and humans.

\section{A. Temperature}

The water samples were taken in a beaker. The temperature was measured using an alcoholic thermometer and the results 
are shown in Figure 3. The temperature ranges between $52^{\circ} \mathrm{C}$ to $57^{\circ} \mathrm{C}$ at location $-1,39^{\circ} \mathrm{C}$ to $42^{\circ} \mathrm{C}$ at location $-2,34^{\circ} \mathrm{C}$ to $36^{\circ} \mathrm{C}$ at location- 3 and $30^{\circ} \mathrm{C}$ to $32^{\circ} \mathrm{C}$ at location-4. The high values of water temperature observed could be attributed to the prevailing monthly summer conditions during the study period.

\section{B. Ammonia $\left(\mathrm{NH}_{3}\right)$}

Ammonia values are shown in Figure 4,which ranges between $50 \mathrm{mg} / 1$ to $55 \mathrm{mg} / 1$ at location- 1 . At location-2, it was $20 \mathrm{mg} / 1$ to $25 \mathrm{mg} / 1$. At location-3, it was $12 \mathrm{mg} / 1$ to $17 \mathrm{mg} / 1$. At location-4, it was $3 \mathrm{mg} / 1$ to $13 \mathrm{mg} / \mathrm{l}$. It is a fact that higher level (concentration) of ammonia causes direct toxic influence on aquatic life at high $\mathrm{pH}$ level. Toxic level of ammonia for fish vary from $0.2-0.5 \mathrm{mg} / \mathrm{l}$. Ammonia toxicity is related to differences between species and $\mathrm{pH}$ rather than to the comparatively minor influences of salinity and temperature. In the marine environment the toxicity of ionized ammonia $\left(\mathrm{NH}_{4}^{+}\right)$should be considered [13].

\section{C. $\mathrm{PH}$}

$\mathrm{PH}$ is an important ecological factor, and water quality detector since aquatic organisms withstand normal $\mathrm{pH}$ and unable to tolerate variations. The surface effluent samples were taken in a beaker for $\mathrm{pH}$ measurements using and the results are shown in Figure 5. It is seen that all samples collected for $\mathrm{pH}$ are alkaline in nature [5]. The highest $\mathrm{pH}$ value was observed at location-1, about ranging from 8.5 to 9.8 .

\section{Total Dissolved Solids (TDS)}

The samples were taken in a beaker, and the multimeter probe was placed for few minutes. The TDS levels (Figure 6) vary from $2275 \mathrm{mg} / 1$ to $2300 \mathrm{mg} / 1$ (Highest) at location-1 to $230 \mathrm{mg} / 1$ to $252 \mathrm{mg} / 1$ at location- 4 , when the limiting value of ECR 1997 is $1000 \mathrm{mg} / 1$ [9].

\section{E. Total Suspended Solids (TSS)}

The level of TSS (Figure 7) was $88 \mathrm{mg} / \mathrm{L}$ to $97 \mathrm{mg} / 1$ at location-1. At location-2, it was $72 \mathrm{mg} / 1$ to $83 \mathrm{mg} / 1$. At location3 , it was $68 \mathrm{mg} / 1$ to $77 \mathrm{mg} / \mathrm{l}$. At location- 4 , it was $64 \mathrm{mg} / \mathrm{L}$ to $66 \mathrm{mg} / 1$. All values were within standard limits.

\section{F. Biochemical Oxygen Demand $\left(\mathrm{BOD}_{5}\right)$}

Biochemical oxygen demand $\left(\mathrm{BOD}_{5}\right)$ is the measure of the dissolved oxygen (DO), required by the microorganisms to decay the organic matter present in a water sample. The sample taken in the beaker was first diluted with water. After inserting the probe, reading was taken, and finally, the beaker was placed inside the refrigerator at $200^{\circ} \mathrm{C}$ for 5 days. Afterwards, the data was retaken, and the result was obtained. The value of $\mathrm{BOD}_{5}$ (Figure 8) ranges from $150 \mathrm{mg} / 1$ to $182 \mathrm{mg} / \mathrm{l}$ at location- 1 . At location-2, it ranges between $115 \mathrm{mg} / 1$ to $126 \mathrm{mg} / 1$. At location-3, it ranges between $110 \mathrm{mg} / 1$ to $123 \mathrm{mg} / 1$. At location4 , it ranges from $100 \mathrm{mg} / 1$ to $105 \mathrm{mg} / \mathrm{l}$. The high values at location-1, may cause severe hypoxia problem into streams, canal, and other enclosed water bodies [10].

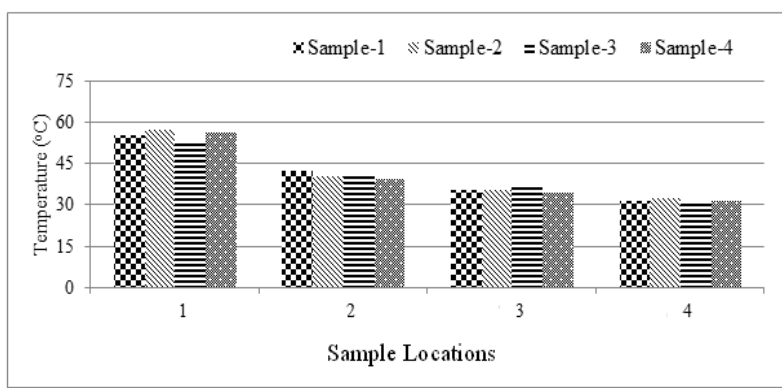

Fig. 3. Variation in temperature

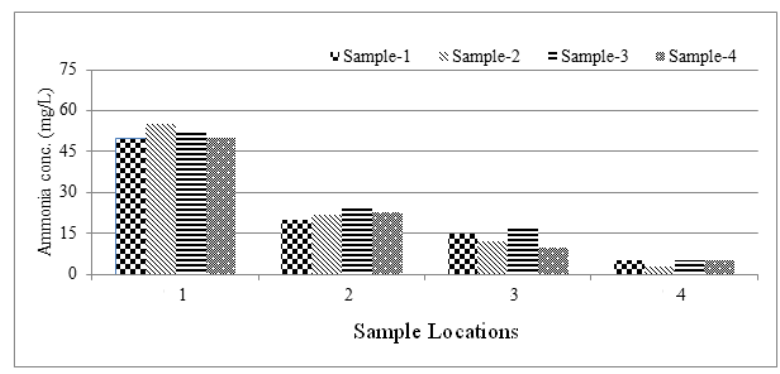

Fig. 4. Variation in ammonia

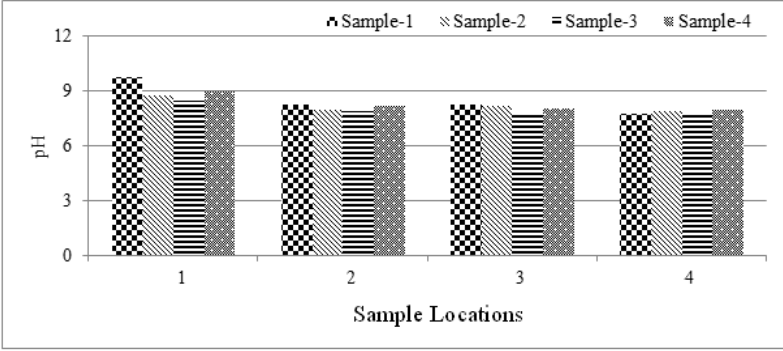

Fig. 5. Variation in $\mathrm{pH}$

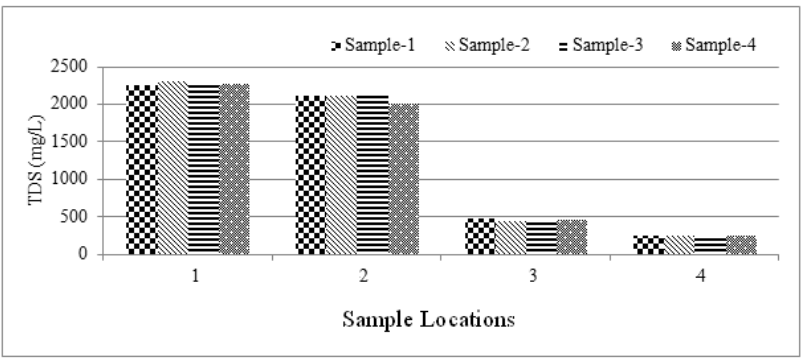

Fig. 6. Variation in TDS

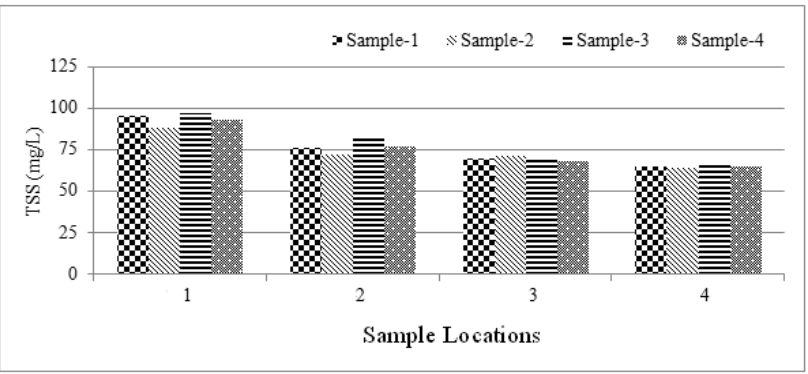

Fig. 7. Variation in TSS 


\section{G. Chemical Oxygen Demand (COD)}

Chemical oxygen demand (COD) is a measure of oxygen required to decompose organic and inorganic waste equivalent to the amount of dichromate (oxidizing agent) consumed by dissolved and suspended matter under specific conditions [11]. The value of COD measured (Figure 9) ranges between $105 \mathrm{mg} / 1$ to $110 \mathrm{mg} / 1$ at location- 1 . At the location-2, it ranges between $80 \mathrm{mg} / 1$ to $88 \mathrm{mg} / 1$. At location-3, it ranges between $70 \mathrm{mg} / 1$ to $77 \mathrm{mg} / \mathrm{l}$. At location-4, it ranges from $18 \mathrm{mg} / \mathrm{l}$ to $23 \mathrm{mg} / \mathrm{l}$. The permissible limit of COD for drinking water is $255 \mathrm{mg} / 1[5,12]$. Therefore, the observed values of COD for all locations are within allowable limits. COD is the total measurement of all chemicals (organics and in-organics) in the waste water, while $\mathrm{BOD}_{5}$ is a measure of the amount of oxygen required for the bacteria to degrade the organic components present in waste water.

\section{H. $\operatorname{Iron}(\mathrm{Fe})$}

The Fe levels (Figure 10) were $0.21 \mathrm{mg} / 1$ to $0.27 \mathrm{mg} / 1$ at groundwater location G-1. In groundwater location G-2, it was $0.15 \mathrm{mg} / 1$ to $0.19 \mathrm{mg} / 1$. At G-3, it was $0.12 \mathrm{mg} / 1$ to $0.18 \mathrm{mg} / 1$. At G-4, it was $0.11 \mathrm{mg} / 1$ to $0.15 \mathrm{mg} / \mathrm{l}$. The safe limit for drinking water is $0.3 \mathrm{mg} / \mathrm{l}$. The abundance of species such as periphyton, benthic invertebrates and fish diversity are greatly affected by the direct and indirect effects of iron contamination.

\section{Copper (Cu)}

The level of $\mathrm{Cu}$ (Figure 11) was $0.051 \mathrm{mg} / 1$ to $0.055 \mathrm{mg} / \mathrm{l}$ at groundwater location G-1. In groundwater location G-2, it was $0.034 \mathrm{mg} / 1$ to $0.038 \mathrm{mg} / 1$. In groundwater location $\mathrm{G}-3$, it was $0.041 \mathrm{mg} / 1$ to $0.045 \mathrm{mg} / 1$. In the groundwater location $\mathrm{G}-4$, it was $0.035 \mathrm{mg} / 1$ to $0.039 \mathrm{mg} / \mathrm{l}$. Toxicity from $\mathrm{Cu}$ is rare, World Health Organization (WHO) suggest a safe consumsion upper limit $12 \mathrm{mg} /$ day for adults and $150 \mu$ /day for children [14].

\section{J. Chromium (Cr)}

The level of Cr (Figure 12) was $0.018 \mathrm{mg} / 1$ to $0.021 \mathrm{mg} / 1$ at groundwater location G-1. At G-2, it was $0.011 \mathrm{mg} / 1$ to $0.018 \mathrm{mg} / 1$. At G-3, was $0.02 \mathrm{mg} / 1$ to $0.025 \mathrm{mg} / 1$. In G-4, it was $0.011 \mathrm{mg} / 1$ to $0.018 \mathrm{mg} / 1$. A suggested upper limit in the United Kingdom is $400 \mathrm{mg} / \mathrm{kg}$, and in the United States $1000 \mathrm{mg} / \mathrm{kg}$. Due to the presence of excess oxygen in the environment, $\mathrm{Cr}$ (III) is oxidized to $\mathrm{Cr}$ (VI), which is extremely toxic and highly soluble in water [19].

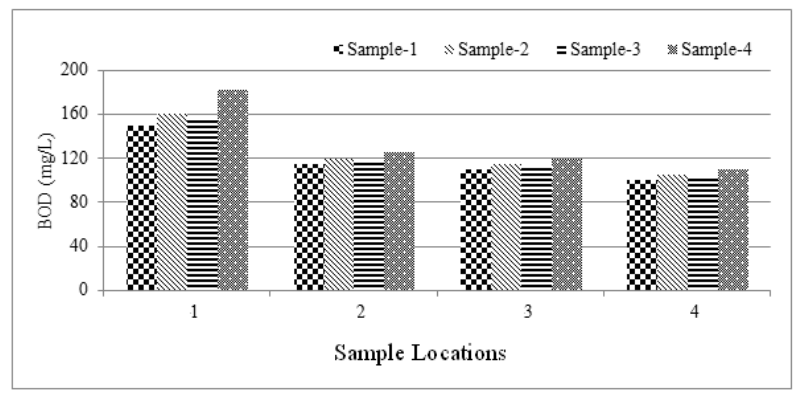

Fig. 8. Variation in $\mathrm{BOD}_{5}$

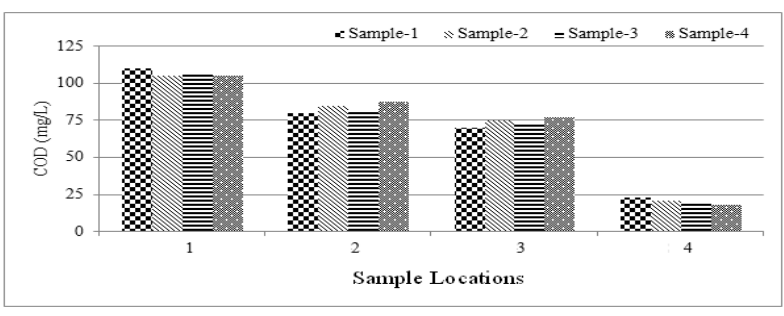

Fig. 9. Variation in COD

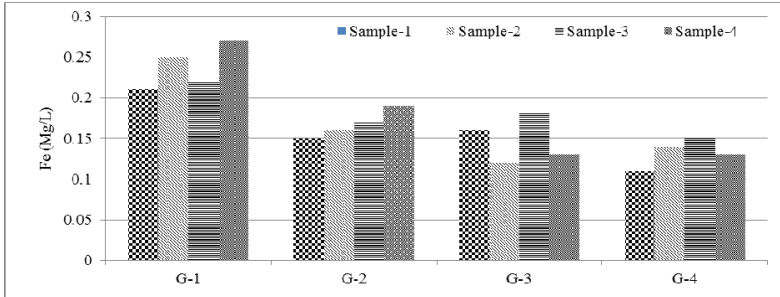

Fig. 10. Variation in $\mathrm{Fe}$

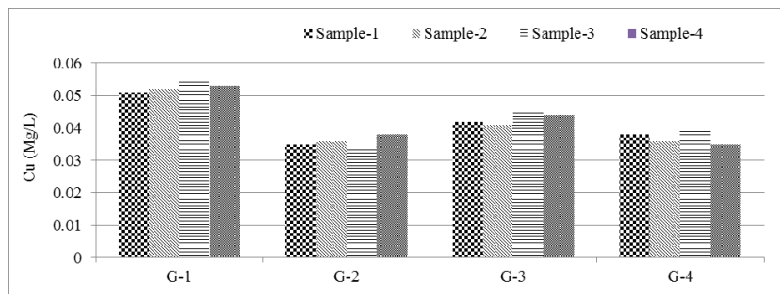

Fig. 11. Variation in $\mathrm{Cu}$

\section{K. Manganese (Mn)}

The level of Mn (Figure 13) was $0.042 \mathrm{mg} / 1$ to $0.047 \mathrm{mg} / 1$ at the G-1. At G-2, it was $0.034 \mathrm{mg} / 1$ to $0.038 \mathrm{mg} / 1$. At G-3, it was $0.028 \mathrm{mg} / 1$ to $0.029 \mathrm{mg} / 1$. At $\mathrm{G}-4$, it was $0.021 \mathrm{mg} / 1$ to $0.025 \mathrm{mg} / 1$. The standard for manganese is $0.05 \mathrm{mg} / \mathrm{l}$.

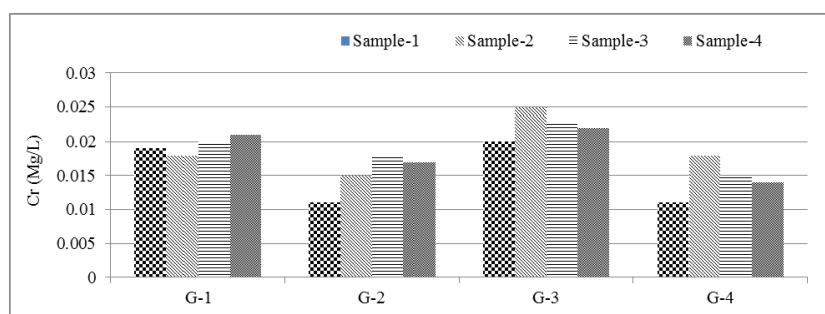

Fig. 12. Variation in $\mathrm{Cr}$

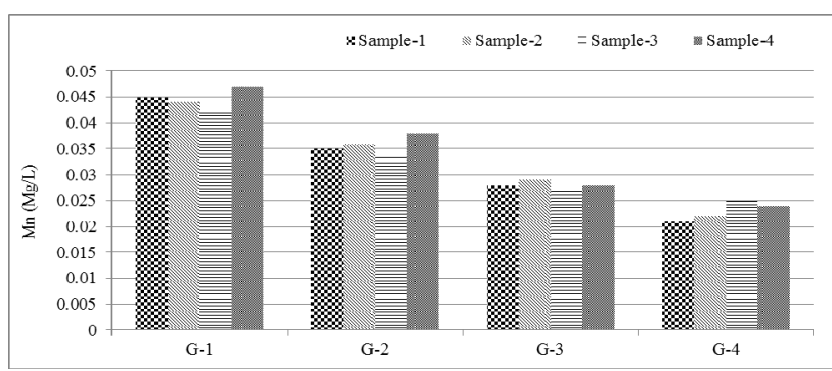

Fig. 13. Variation in Mn 


\section{CONCLUSIONS}

The study has shown that effluents discharged into surface canal water cause drastic impacts on the aquatic life, animals, plants and humans. The effluents discharged into the canal have increased temperature compared to given industrial limit. The results from samples taken from surface water represent that the effluents discharged from the plant contain adverse impacts on the quality of surface water. The continued discharge of the effluents in the canal may result in severe accumulation of the contaminants. Sample analysis further showed that $\mathrm{BOD}_{5}$ and ammonia levels are at alarming rates, which is hazardous for aquatic life, animals and humans. The open survey form the sample location revealed that the nearby residents suffer from several diseases that can be linked to the urea plant. The observed diseases include both common health issues (such as diarrhea, skin rash, indigestion, respiratory problems, hypertension) and complex and critical health diseases (i.e., gastric ulcer gout, rheumatism, conjunctivitis, pneumonia, malaria, tuberculosis and even cancer). Heavy metals are too dangerous, even though they are found within safe limits, because they have the potentiality to accumulate in organisms over time.

\section{RECOMMENDATIONS}

It is recommended that plant wastewater should not be discharged untreated. Treatment process must be updated as a high level of ammonia, and $\mathrm{BOD}_{5}$ are found in the test results. Liquid effluents discharged from urea fertilizer plant through the sampling point-1 must be managed according to standard procedures. Leakage from pipeline, valves or ammonia storage tank should be prevented through regular maintenance. The quality of surface canal water where plant effluents are discharged should be checked on a continuous basis to ensure its quality. The proper and effective implementation of national and international laws and regulations related to industrial effluents regarding wastewater. Medical and financial assistance should be given to nearby residents who are continuously suffering from plant effluents and are also bearing the financial loss of their animals' deaths.

\section{REFERENCES}

[1] K. Saeed-ur-Rehman, A. Wahid, R. B. Tareen, S. A. Kakar, M. Tariq, S. A. Kayani, "Impact of municipal waste water of Quetta city on biomass, physiology and yield of canola (Brassica napus L.)", Pakistan Journal of Botany, Vol. 42, No. 1, pp. 317-328, 2010

[2] D. Balabanic, M. Filipic, A. K. Klemencic, B. Zegura, "Raw and biologically treated paper mill wastewater effluents and the recipient surface waters: Cytotoxic and genotoxic activity and the presence of endocrine disrupting compounds", The Science of Total Environment, Vol. 574, pp. 78-89, 2017

[3] M. A. Khattak, N. Ahmed, M. A. Qazi, A. Izhar, S. Ilyas, M. N. Chaudhary, M. S. A. Khan, N. Iqbal, T. Waheed, "Evaluation of ground water quality for irrigation and drinking purposes of the areas adjacent to Hudiara Industrial Drain, Lahore, Pakistan", Pakistan Journal of Agricultural Sciences, Vol. 49, No. 4, pp. 549-556, 2012

[4] M. H. Islam, M. Rahman, F. U. Ashraf, "Assessment of water quality and impact of effluents from fertilizer factories to the Lakhya River", International Journal of Water Resources and Environmental Engineering, Vol. 2, No. 8, pp. 208-221, 2010

[5] R. Shyamala, M. Shanthi, P. Lalitha, "Physicochemical Analysis of Borewell Water Samples of Telungupalayam Area in Coimbatore
District, Tamilnadu, India”, E-Journal of Chemistry, Vol. 5, No. 4, pp. 924-929, 2008

[6] M. B. Pescod, Wastewater treatment and use in agriculture - FAO irrigation and drainage paper 47, FAO, 1992

[7] A. M. Abdel-Satar, M. H. Ali, M. E. Goher, "Indices of water quality and metal pollution of Nile", The Egyptian Journal of Aquatic Research, Vol. 43, No. 1, pp. 21-29, 2017

[8] J. N. Halder, M. N. Islam, "Water Pollution and its Impact on the Human Health", Journal of Environment and Human, Vol. 2, No. 1, pp. 36-46, 2015

[9] Ministry of Environment and Forest, The Environment Conservation Rules, 1997, Government of the People's Republic of Bangladesh, Ministry of Environment and Forest, 1997

[10] M. A. Mallin, V. L. Johnson, S. H. Ensign, T. A. MacPherson, "Factors contributing to hypoxia in rivers, lakes, and streams", Limnology and Oceanography, Vol. 51, No. 1, part 2, pp. 690-701, 2006

[11] R. B. Geerdink, R. S. van den Hurk, O. J. Epema, "Chemical oxygen demand: Historical perspectives and future challenges", Analytica Chimica Acta, Vol. 961, pp. 1-11, 2017

[12] WHO, Guidelines for Drinking-Water Quality, WHO, 2011

[13] F. B. Eddy, "Ammonia in estuaries and effects on fish", Journal of Fish Biology, Vol. 67, No. 6, pp. 1495-1513, 2005

[14] M. Oliver, "Soil, food security and human health: a review", European Journal of Soil Science, Vol. 66, No. 2, pp. 257-276, 2015 